\title{
IMPACT OF ENVIRONMENTAL TAXES ON SUSTAINABLE ENERGY DEVELOPMENT IN BALTIC STATES, CZECH REPUBLIC AND SLOVAKIA
}

\section{Dalia Štreimikienè}

\section{Introduction}

Economic stabilization policies can be implemented with the aid of either monetary or fiscal policy. A forward-looking, mediumterm oriented monetary policy provides the best framework to this purpose. Fiscal policies too should have a medium to longterm orientation and largely rely on automatic stabilizers in the short-term. Fiscal policy can promote macroeconomic stability by sustaining aggregate demand and private sector incomes during an economic downturn and by moderating economic activity during periods of strong growth. An important stabilizing function of fiscal policy operates through the so-called "automatic fiscal stabilizers". These work through the impact of economic fluctuations on the government budget and do not require any short-term decisions by policy makers. The size of tax collections and transfer payments, for example, are directly linked to the cyclical position of the economy and adjust in a way that helps stabilizing aggregate demand and private sector incomes. Automatic stabilizers have a number of desirable features. First, they respond in a timely and foreseeable manner. This helps economic agents to form correct expectations and enhances their confidence. Second, they react with an intensity that is adapted to the size of the deviation of economic conditions from what was expected when budget plans were approved. Third, automatic stabilizers operate symmetrically over the economic cycle, moderating overheating in periods of booms and supporting economic activity during economic downturns without affecting the underlying soundness of budgetary positions, as long as fluctuations remain balanced [17].

In principle, stabilization can result from discretionary fiscal policy-making, whereby governments actively decide to adjust spending or taxes in response to changes in economic activity. The main fiscal and pricing policies aiming at implementation of sustainable energy development are related with promotion of sustainable energy which is the major source of environmental problems in EU [12]. The European Semester was established in 2010 as a mechanism to better coordinate economic policies in European Union countries. It was one of the EU's responses to the financial and economic crisis, which has resulted in economic contraction and rising unemployment in many EU countries. The European Semester is based on the idea that, because EU economies are highly integrated, enhanced policy coordination can help boost economic development in the EU generally. 'Greening the European Semester' is aimed to ensure that macroeconomic policies of EU member states are sustainable, not only economically and socially, but also environmentally. Environmental policies can contribute to sustainable economic recovery and jobs growth in many ways. Resource efficiency is clearly such a contribution, but there are many more themes, such as environmental fiscal reform, including tax shifts from labour to environmental pollution. European Commission prepares each year Country Specific Recommendations, and the Member States update their National Reform Programmes annually based on these recommendations. The main priorities identified by EC to be addressed by EU member states in their National Reform Programmes are the following:

- Taxation system should be designed to be more growth-friendly, by shifting the tax burden away from labor to taxes linked to consumption and combating pollution;

- Increase of resource efficiency and reduction of EU energy dependency;

- Promotion of resource efficiency by energy efficiency and recycling. 
The aim of this paper is to review fiscal and pricing policies aiming at promotion of sustainable energy development in some new EU member states and to carry out comparative assessment of environmental taxes targeting sustainable energy development and achieved sustainable energy development targets in selected new EU member states.

Seeking to achieve this aim the main tasks are:

- to review literature on the impact of fiscal policies on promoting sustainable energy development;

- to define the main environmental taxes targeting sustainable energy development;

- to define the main indicators of sustainable energy development;

- to analyse environmental taxes aiming at promotion of sustainable energy development in Baltics and Czech Republic and Slovakia;

- to analyse sustainable energy development indicators in in Baltics and Czech Republic and Slovakia;

- to develop the main findings of analysis conducted.

The methods applied are comparative analysis, graphical analysis, generalization.

\section{Environmental Taxes and Green Budget Reform}

The environment protection is one of the important priorities to government institutions. Economic instruments such as taxes, tradeable permits or subsidy reform promise to achieve both environmental and economic objectives by raising the cost of environmentally harmful activities and at the same time lowering the cost of labour [13], [15]. The general idea has been around for quite some time, and instruments like Germany's green budget reform efforts in 1999-2003 [2] or the EU Emissions Trading demonstrate that such instruments work in principle - notwithstanding the widespread and often justified criticisms of their specific design and implementation ([4], [11], [19]). In important papers by Bovenberg and others ([6], [7], [8]) it was tested whatever the increasing the tax rate on a polluting good from its Pigovian level, and reducing pre-existing labor taxes in a revenue neutral fashion, will deliver a welfare gain. The main findings of the paper showed that, although environmental quality improved, the efficiency dividend didn't materialize. There are other important paper in this area as well. In his paper Lucas [22] showed that shifting capital income taxation completely to labor income taxation has negligible effects on longrun economic growth in a model of endogenous growth which is calibrated to the U.S. economy. A similar theoretical results were obteined in several papers ([21], [5], [3]). They showed that, in a distorted labor market, substituting green taxes for labor taxes would increase employment and output and have eventually produce a detrimental effect on the environment and income. In other papers ([20], [18], [9], [27]) authorsused a dynamic general equilibrium model to assess the impact of green tax reform. The results of effects of green tax reform is summarized in [10]. The recent developments of green budget reforms in EU member states were overwied in EU ([16], [15], [1]).

Economic instruments for pollution control and natural resource management are an increasingly important part of environmental and energy policy in the EU Member States. The range of instruments that are available and have impact on energy sector development trends includes environmental taxes, fees and charges, tradable permits and subsidies [1].

The environmental tax is one whose tax base is a physical unit (or a proxy of it) of something that has a proven, specific negative impact on the environment. Environmental taxes can be of four types: energy, transport, pollution and resource taxes. Energy taxes include taxes on energy products (e.g. coal, oil products, natural gas and electricity) used for both stationary purposes and transport purposes. In 2011 almost $75 \%$ of all environmental taxes were energy taxes. By convention, $\mathrm{CO}_{2}$ taxes are also included in this tax category since they are usually levied on energy products. Including $\mathrm{CO}_{2}$ taxes with pollution taxes rather than energy taxes would distort international comparisons. Transport taxes mainly include taxes related to the ownership and use of motor vehicles. Pollution and resource taxes cover different types of taxes: taxes on the extraction of raw materials; on measured or estimated emissions to air (e.g. $\mathrm{NO}_{x}$ and $\mathrm{SO}_{2}$ ) and water; on noise and on the management of waste.

Environmental taxes have been increasingly used in energy sector to influence the behaviour of economic agents whether producers or consumers. These instruments provide a flexible and cost-effective means for 
reinforcing the polluter-pays principle and for reaching environmental policy objectives in energy sector. The use of economic tools for the benefit of the environment in energy sector is promoted in the EU Environment Action Programme to 2020 - 7th environment action programme (EAP), the renewed EU sustainable development strategy and the Europe 2020 strategy.

Environmental tax revenue as a percentage of GDP has gradually fallen in EU, reaching a historical minimum of $2.32 \%$ in 2008 . During the 2009-2012 it has been steady around $2.39 \%$. The distribution of the tax categories has remained roughly the same [1].

In environmental taxes energy taxes (which include taxes on transport fuels) represented by far the highest share of overall environmental tax revenue, accounting for $75.0 \%$ of the EU28 total in 2013. These taxes were particularly prominent in Lithuania and the Czech Republic, where they accounted for more than nine tenths of total environmental tax revenues. In some countries like Malta and Norway energy taxes slightly exceeded $50 \%$ of the revenues from environmental taxes.

Transport taxes represented the second most important contribution to total environmental tax revenues, with $20.1 \%$ of the EU-28 total in 2013. The smallest shares of transport taxes in total revenues from environmental taxes (less than $3.0 \%$ ) were in Lithuania and in Estonia.

Pollution and resource taxes represented a relatively small share $(4.9 \%)$ of total environmental tax revenues in the EU-28 in 2013. This category of taxes was implemented more recently in most European countries. In some EU Member States no taxes of this category have been levied. This can be due to specificities in the management of water and waste charges which may be collected by schemes other than taxes. Quite high share for pollution and resource taxes was observed in Slovakia (15.3\%) and very low in Latvia. In the following section of paper the revenues of environmental taxes in Baltic States and Czech Republic and Slovakia were analysed in detail.

\section{Environmental Tax Revenues in Baltic States, Czech Republic and Slovakia}

The total revenue from environmental taxes in the EU-28 in 2013 was EUR 331 billion or 2.5\% of gross domestic product (GDP) and to $6.3 \%$ of the total revenues derived from all taxes and social contributions (TSC) in EU. In 2013, $21 \%$ of EU-27 total environmental tax revenue came from transport taxes. Only $4 \%$ of EU-27 total environmental tax revenue was raised by pollution and resource taxes in 2011. Compared with 1995, environmental tax revenue has increased by more than 110 billion EUR, which is an increase of $59 \%$, but as percentage of GDP (and TSC) it has declined.

Though environmental tax revenues increased in value since 2009 , the relation of these taxes to GDP and to the total revenue from all taxes and social contributions decreased. From 2006 to 2008, the ratio of EU-28 environmental tax revenue to GDP decreased modestly from $2.4 \%$ to $2.3 \%$ because environmental tax revenues rose at a slower pace than overall economic growth. In 2009, the ratio increased again due to a decrease of GDP which was more pronounced than the one for environmental tax revenue. Since 2009 , the environmental tax revenues relative to GDP remained quite stable, around $2.4 \%$. Environmental tax revenues as a share of total revenue from taxes and social contributions decreased from $6.4 \%$ to $6.0 \%$ during 2006 2008 period. After a recovery from economic crisis in 2009, the ratio was $6.3 \%$ [1].

When comparing the level of environmental taxation across European countries, differences should be analysed with caution. Low revenues from environmental taxes could signal relatively low environmental tax rates, or could result from high tax rates that have had the effect of changing behavioural patterns of consumption of the related products or activities. On the other hand, higher levels of environmental tax revenue could be due to low tax rates that incentivise non-residents to purchase taxed products across a border (as is the case for petrol or diesel) after implementation of high excise duties. In any case the comparison of the share of revenues as a percentage to GDP is a good indicator to compare EU member states in terms of importance of environmental taxes playing in state budget revenues and achievements in implementing green budget reforms.

Figure 1 shows the dynamics of environmental tax revenues in relation to GDP in Baltic States, Czech Republic and Slovakia. 
Revenues from environmental taxes in Baltic States and Czech Republic and Slovakia as the percentage of GDP
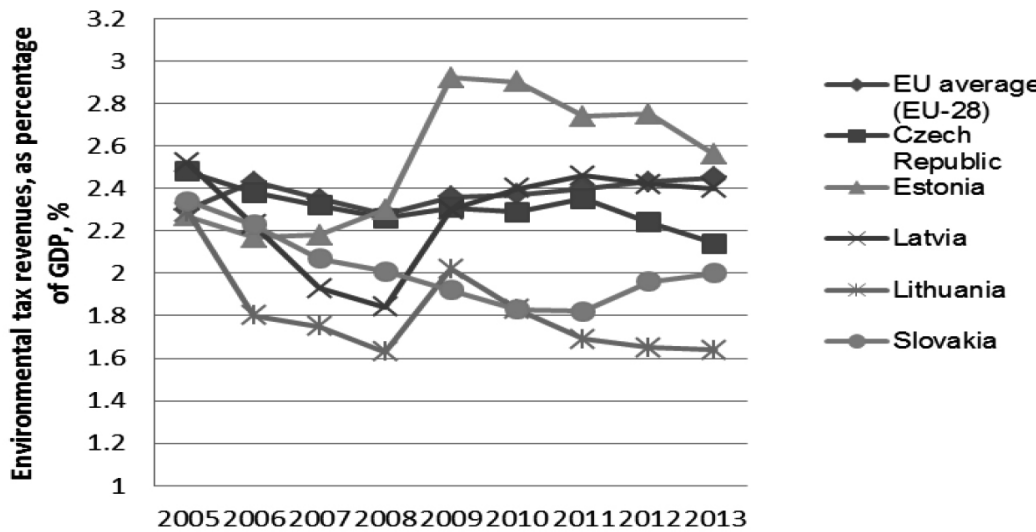

Source: EUROSTAT

As one can see from Figure 1 in 2013, the lowest ratios of environmental tax revenues to GDP were recorded in Lithuania, below $2.0 \%$, following by Slovakia and Czech Republic. In Latvia the share of environmental revenues from GDP was similar to EU-28 average level in 2013.
The highest share of GDP by environmental revenues can be noticed in Estonia though the trends show significant decline after economic crisis in 2008. The same trend can be noticed in all analysed countries except Slovakia. As one can see from Figure 1 the environmental taxes and Slovakia as the percentage of GDP

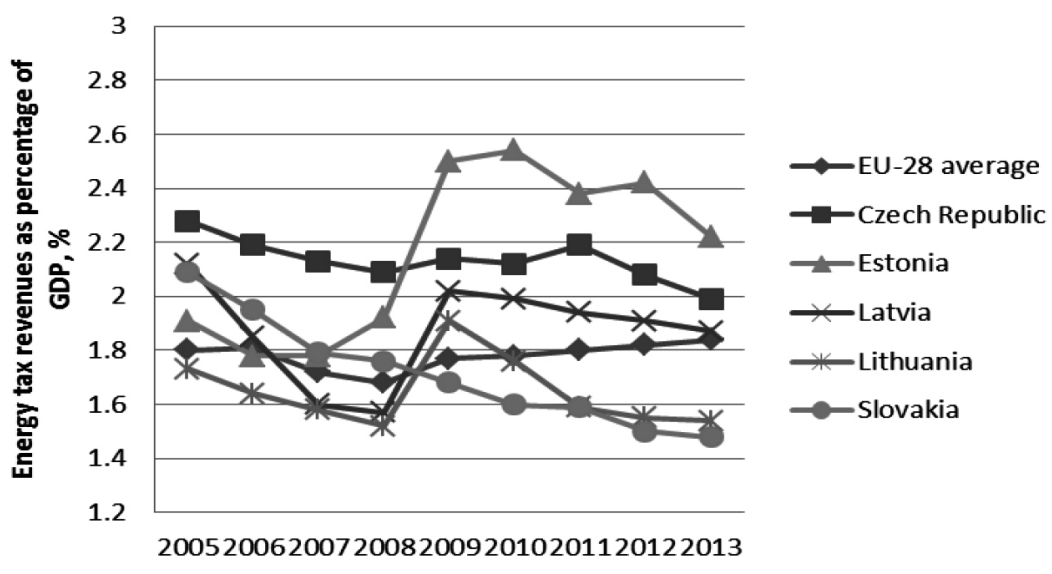


per share of GDP were declining since 2005 to 2011 and are increasing since 2012 though other countries are experiencing the trend of decrease onwards 2013.

In Figure 2 dynamics of revenues from energy taxes in Baltic States, Czech Republic and Slovakia is presented.
Comparing the environmental tax revenues according specific categories relevant to energy sector between Baltic States and Czech Republic and Slovakia, one can notice that the highest share of energy tax revenues to GDP is in Estonia and the lowest one in Slovakia (Figure 2).

\section{Fig. 3: Dynamics of revenues from pollution taxes in Baltic States and Czech Republic and Slovakia as the percentage of GDP}

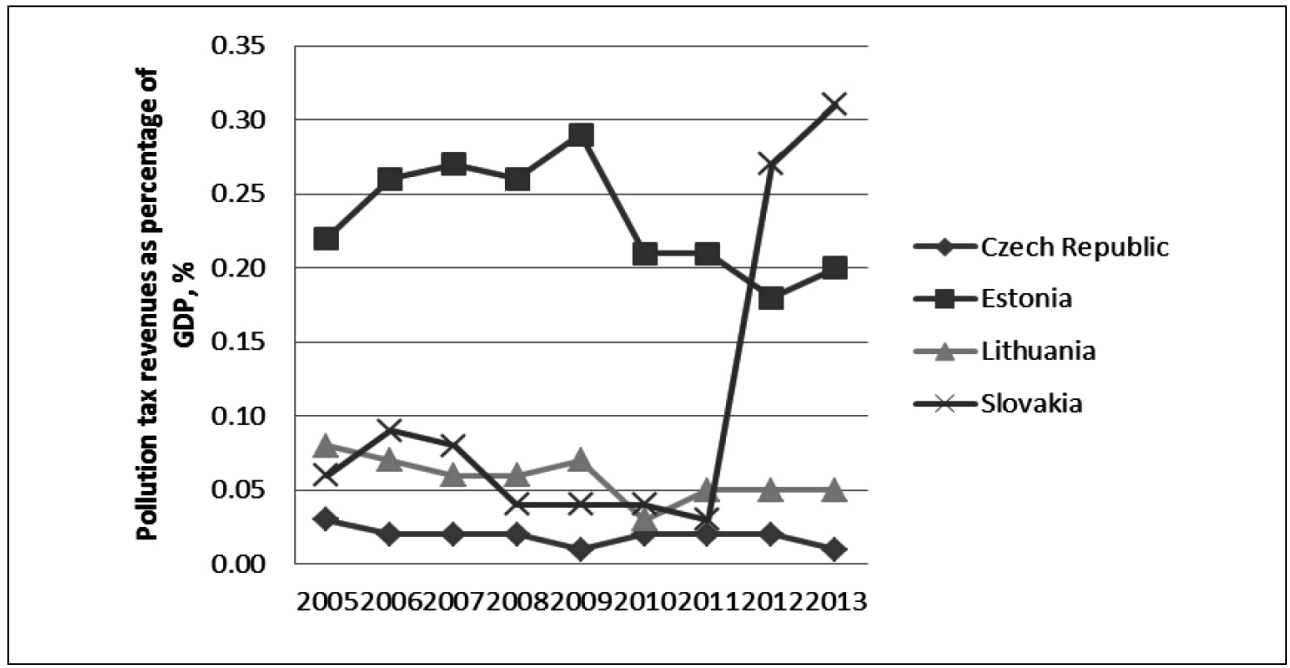

Source: EUROSTAT

In Figure 3 the dynamics of revenues from Pollution taxes as percentage of GDP in Baltic States, Czech Republic and Slovakia are presented.

Comparing revenues from pollution taxes as the percentage of GDP between analysed countries one can noticed that the highest share of pollution taxes to GDP is in Slovakia and Estonia. The lowest share is in Latvia (Fig. 3). The steep increase of the share of pollution taxes as percentage of GDP in Slovakia can be noticed in year 2011. This indicates that country is looking forward to green budget reform. In Latvia pollution taxes are very low and do not represent comparable share of GDP for comparative analysis between selected member states. Also very low revenues of pollution taxes to GDP are in Lithuania and Czech Republic.

The dynamics of revenues from environmental taxes as the percentage of total taxes and social contributions in Baltic States, Czech Republic and Slovakia are presented in Figure 4.

As one can see from Figure 4 the highest share of environmental tax revenues to total taxes and social contributions was in Latvia following by Estonia in 2013. The lowest share of environmental taxes was in Czech Republic and Lithuania however these shares correspond to EU-28 average level. When comparing environmental tax revenue to total taxes and social contributions a vast majority of European countries showed levels of environmental tax revenue in a band ranging from $6 \%$ to $10 \%$ of total taxes and social contributions in 2012. The EU-28 average was $6.2 \%$ of total taxes and social contributions in 2013.

Across those EU Member States for which a distribution of 2013 data by economic activity is available, businesses paid half $(50 \%)$ of all 
Fig. 4: Dynamics of revenues from environmental taxes in Baltic States and Czech Republic and Slovakia as the percentage of total taxes and social contributions

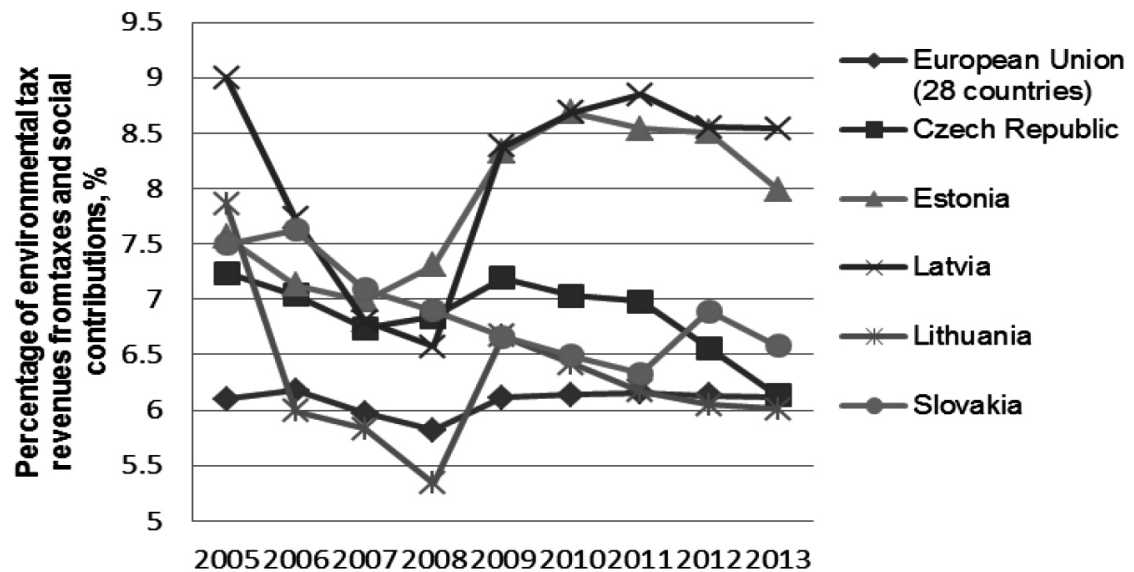

Source: EUROSTAT

energy tax revenue, while the contribution of households rose to $48 \%$. The remainder (2\%) was paid by non-residents. The share of energy taxes paid by households was highest in Slovenia (74\%) between all EU member states. The share of taxes borne by households was lowest in Czech Republic (20\%). Generally the highest share of energy tax revenues from businesses came from industry, construction and services other than those related to transportation and storage. The shares for this activity grouping ranged between $15 \%$ and $59 \%$ of total energy taxes. The share of energy taxes borne by transport varied, from $5 \%$ in Slovenia to $30 \%$ in Estonia. The contribution of agriculture, forestry and fishing to the total energy taxes was less than $3.0 \%$ in most of the EU Member States.

There is important indicator used by EUROSTAT - the implicit tax rate on energy showing the importance of energy taxation in energy sector and economy of the country. The higher is implicit tax rate the higher taxation burden is imposed on energy consumption in the country. It is defined as the ratio of energy tax revenues to final energy consumption calculated for a calendar year. Energy tax revenues are measured in constant price euros (deflated with the final demand deflator) and final energy consumption is measured in tonnes of oil equivalent (toe); as such the implicit tax rate on energy is expressed in terms of euros per tonne of oil equivalent (EUR per toe). The implicit tax rate on energy is not influenced by the size of the tax base and provides a measure of the effective level of energy taxation. From 2006 to 2013, the implicit tax rate on energy increased by $11 \%$ in real or after deflating the energy tax revenue, prices of year 2010 and changing from EUR 191.8 per toe to EUR 212.3 per toe. However two dips were observed during this period: the first one in 2008 was due to a decline in energy tax revenue; the second one in 2010 resulted from a substantial recovery in energy consumption (following a strong reduction in 2009) which exceeded the increase of energy tax revenue in the same year. In Figure 5 implicit tax rate on energy is presented for analysed countries.

As one can see from Figure 5 the highest implicit tax rate in 2013 was in Estonia and Czech Republic and lowest in Slovakia, followed by Latvia and Lithuania. Therefore effective energy tax level is the highest in Czech Republic and Estonia.

In the next section of paper the environmental tax rates will be compared between Baltic States 


\section{Fig. 5: Implicit energy tax in Baltic States, Slovakia and Czech Republic}

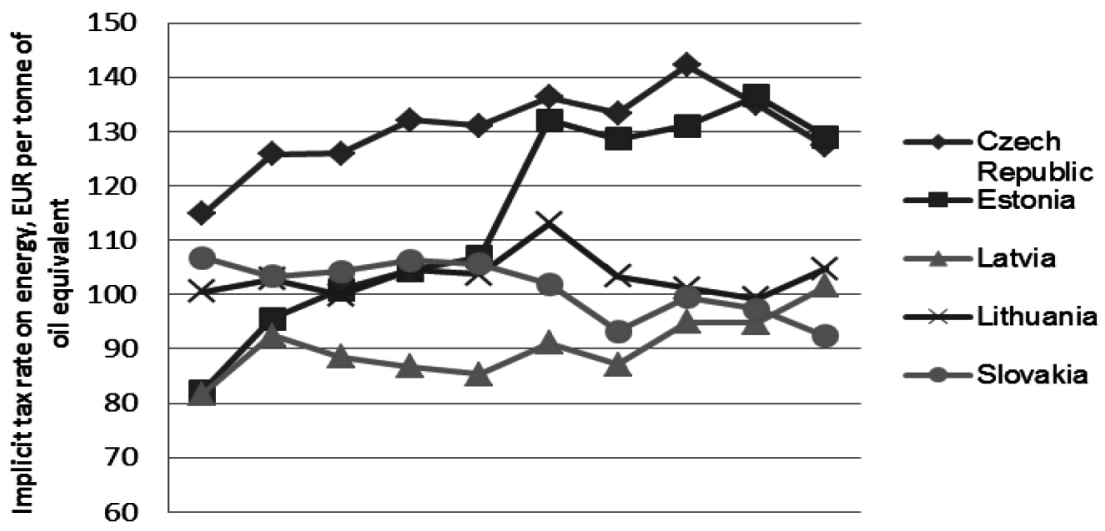

2004200520062007200820092010201120122013

and Czech Republic and Slovakia with the aim to define why there are such huge differences between analysed countries in effective tax rates and revenues from environmental taxes targeting energy sector.

\section{Environmental Tax Rates in Baltic States, Czech Republic and Slovakia}

In energy sector the most important environmental taxes are energy taxes and pollution taxes. These taxes are the main economic tools affecting behaviour of economic agents in energy sector.

EU Energy tax Directive (2003/96/EEC) establishes the minimum rates for energy products and electricity. The tax rates of excise duties on energy products and electricity in Baltic States and Slovakia and Czech Republic are given in Table 1 alongside minimum rates set by Energy tax directive and the EU-28 average rates.

The excise duties on energy products and electricity show that all analysed countries are meeting or exceeding minimum rates set out in Energy tax directive. There are just several exemptions: for natural gas Lithuania has exemption under Article 15(1) of energy tax directive. Slovakia has exemption for natural gas used as propellant until 01.01.2020 and the current rate which is lower than minimum rate will be increased gradually until 2020 . Also electricity used for households is exempted from excise duty in Slovakia under Article 15 (1) (h) of Energy Tax directive.

In comparison to EU-28 average Slovakia has higher rates for all energy products except LPG, diesel and natural gas for propellant use. All other excise duties in Slovakia are well above EU-28 average level except natural gas and coal for heating purposes. Czech Republic has quite similar duty rates to Slovakia however in some cases like natural gas for propellant use and LPG for commercial use the rates are significantly lower than in Slovakia and other analysed countries. In comparison to the EU-28 average rates Lithuania is well below average European rates. In Latvia all excise duties are well below EU-28 average and almost in all cases bellow tax rates of all analysed countries except LPG for propellant use rate which is lower in Estonia. Latvia distinguishes with very low rates for gasoil and kerosene comparing with other analysed countries. In Estonia the 


\begin{tabular}{|c|c|c|c|c|c|c|c|c|}
\hline \multirow[t]{2}{*}{ Tab. 1: } & \multirow[b]{2}{*}{ Unit } & \multirow{2}{*}{$\begin{array}{l}\text { 3altic Stat } \\
\text { at } 1^{\text {st }} \text { July } \\
\begin{array}{c}\text { Czech } \\
\text { Republic }\end{array}\end{array}$} & \multirow{2}{*}{$\begin{array}{l}\text { es, Sloval } \\
2015, \text { EU } \\
\text { Slovakia }\end{array}$} & \multirow[b]{2}{*}{ Lithuania } & \multirow[b]{2}{*}{ Latvia } & \multirow[b]{2}{*}{ Estonia } & \multirow[b]{2}{*}{$\begin{array}{c}\text { Minimal } \\
\text { rate }\end{array}$} & \multirow[b]{2}{*}{$\begin{array}{c}\text { EU-28 } \\
\text { average }\end{array}$} \\
\hline & & & & & & & & \\
\hline \multicolumn{9}{|l|}{ Transport fuels } \\
\hline Leaded Petrol & $\begin{array}{l}\text { per } 1000 \\
\text { litres }\end{array}$ & 498.5 & - & 579.0 & 455.3 & 422.8 & 421.0 & 580.0 \\
\hline Unleaded Petrol & \begin{tabular}{|l|} 
per 1000 \\
litres
\end{tabular} & 466.9 & 550.5 & 434.0 & 411.2 & 422.8 & 359.0 & 511.0 \\
\hline Diesel (Gas oil) & \begin{tabular}{|l|} 
per 1000 \\
litres
\end{tabular} & 398.2 & 386.4 & 330.0 & 333.0 & 392.9 & 330.0 & 425.0 \\
\hline Kerosene & $\begin{array}{l}\text { per } 1000 \\
\text { litres }\end{array}$ & 398.2 & 481.3 & 330.0 & 333.0 & 330.1 & 330.0 & 434.0 \\
\hline LPG & \begin{tabular}{|l|}
$\begin{array}{l}\text { per } 1000 \\
\mathrm{~kg}\end{array}$ \\
\end{tabular} & 143.0 & 182.0 & 304.0 & 161.0 & 125.3 & 125.0 & 197.0 \\
\hline Natural gas & Per GJ & 0.69 & 2.6 & 6.55 & 2.67 & n.a. & 2.6 & 2.9 \\
\hline \multicolumn{9}{|c|}{ Motor fuels-Industry/Commercial use } \\
\hline Gas Oil & \begin{tabular}{|l} 
per 1000 \\
litres
\end{tabular} & 398.2 & 386.4 & 330.0 & 56.9 & 392.9 & 21.0 & 233.0 \\
\hline Kerosene & \begin{tabular}{|l|} 
per 1000 \\
litres
\end{tabular} & 398.2 & 481.3 & 330.0 & 21.3 & 330.1 & 21.0 & 300.0 \\
\hline LPG & per $1000 \mathrm{~kg}$ & 46.9 & 182.0 & 304.0 & 161.0 & 125.3 & 41.0 & 134.0 \\
\hline Natural gas & per GJ & 0.31 & 2.6 & - & 0.46 & n.a. & 0.3 & 1.9 \\
\hline \multicolumn{9}{|c|}{ Heating -Business use } \\
\hline Gas Oil & $\begin{array}{l}\text { per } 1000 \\
\text { litres }\end{array}$ & 398.2 & 386.4 & 21.0 & 56.9 & 111.0 & 21.0 & 178.0 \\
\hline Kerosene & \begin{tabular}{|l|}
$\begin{array}{l}\text { per } 1000 \\
\text { litres }\end{array}$ \\
\end{tabular} & 398.2 & 481.3 & 330.0 & 21.3 & 330.1 & 0 & 265.0 \\
\hline $\mathrm{HFO}$ & per $1000 \mathrm{~kg}$ & 17.2 & 111.5 & 15.0 & 15.7 & 15.0 & 15.0 & 71.0 \\
\hline LPG & per $1000 \mathrm{~kg}$ & 0 & 0 & 0 & 0 & n.a. & 0 & 78.0 \\
\hline Natural gas & per GJ & 0.31 & 0.37 & 0 & 0.46 & 0.84 & 0.15 & 1.38 \\
\hline Coal and coke & per GJ & 0.31 & 0.31 & 0.15 & 0.3 & 0.3 & 0.15 & 1.23 \\
\hline \multicolumn{9}{|c|}{ Heating - Not business use } \\
\hline Gas Oil & \begin{tabular}{|l|} 
per 1000 \\
litres
\end{tabular} & 398.2 & 386.4 & 21.0 & 56.9 & 111.0 & 21.0 & 185.0 \\
\hline Kerosene & $\begin{array}{l}\text { per } 1000 \\
\text { litres }\end{array}$ & 398.2 & 481.3 & 330.0 & 21.3 & 330.1 & 0 & 275.0 \\
\hline $\mathrm{HFO}$ & per $1000 \mathrm{~kg}$ & 17.2 & 111.5 & 15.0 & 15.7 & 15.0 & 15.0 & 75.0 \\
\hline LPG & per $1000 \mathrm{~kg}$ & 0 & 0 & 0 & 0 & n.a. & 0 & 110.0 \\
\hline Natural gas & per GJ & 0.31 & 0.37 & 0 & 0.46 & 0.84 & 0.3 & 2.11 \\
\hline Coal and coke & per GJ & 0.31 & n.a. & 0.3 & 0.3 & 0.3 & 0.3 & 1.69 \\
\hline \multicolumn{9}{|l|}{ Electricity } \\
\hline Business use & per kWh & 1.03 & 1.32 & 0.52 & 1.01 & 4.47 & 0.5 & 10.2 \\
\hline Non-business use & per kWh & 1.03 & - & 1.01 & 1.01 & 4.47 & 1.00 & 14.7 \\
\hline
\end{tabular}


general approach was to homogenise tax rates across different fuels and for some fuels the rates are well above the minimum set by Energy Tax directive however the majority of rates are bellow the EU-28 average. Electricity duties are set well above the EU-28 average level and well above excise duties of all analysed countries. In general Slovakia and Estonia has the highest excise duties for energy products and Latvia has the lowest one.

Air pollution taxes are important flexible pollution reduction measure in energy sector as energy sector is the major sources of classical pollutants (SO2, NOX, Particulates, $\mathrm{CO}$ ) which are usually being charged by air pollution taxes in major EU member states and other countries all over the world.

The tax rates for the main pollutants discharged from stationary sources of pollution is set for one tonne of pollutants discharged into the environment. The tax rates for pollutants discharged into the atmosphere in analysed countries are presented in Table 2.

Tab. 2: Air pollution tax rates in Baltic States, Czech Republic and Slovakia, valid since 2015, EUR/t

\begin{tabular}{l|r|r|r|r|r} 
& Czech Republic & Slovakia & Lithuania & \multicolumn{1}{c}{ Latvia } & \multicolumn{1}{c}{ Estonia } \\
\hline Ammonia & 38.50 & 66.38 & 4.0 & 18.50 & 122.32 \\
\hline Carbon monoxide & 23.10 & 32.00 & 24.0 & 7.83 & 7.7 \\
\hline Heavy metals & 769.9 & $1,280.2$ & 3,855 & $1,138.3$ & 1,278 \\
\hline Nitrogen oxides & 30.80 & 48.01 & 196 & 85.37 & 122.32 \\
\hline Solid emissions (particulates) & 115.5 & 160.0 & 61 & 75.0 & 146.16 \\
\hline Sulphur dioxide & 38.50 & 64.01 & 104 & 85.37 & 145.5 \\
\hline Volatile organic compounds & 76.99 & 66.38 & 4.0 & 85.37 & 122.32 \\
\hline
\end{tabular}

Source: EUROSTAT

As one can see from information provided in Table 2 the highest rates for classical pollutants in energy sector are being applied in Estonia and Lithuania. The lowest rates for classical pollutants are being applied in Czech Republic and Latvia.

Though selected countries distinguishes with quite different environmental pollution and energy tax rates it can be concluded from analysis of environmental taxes in these countries that Estonia can be considered as country having highest burden of environmental taxes relevant to energy sector between analysed 5 countries. In the following sections of paper analysis of sustainable energy sector development trends will be compared between Baltic States and Czech Republic and Slovakia in order to define the impact of environmental taxes on results achieved by new EU member states in implementing the main EU energy and environmental policy targets. For this purpose sustainable energy development framework and analysis of EU energy policy targets were applied.

\section{Sustainable Energy Development Indicators}

There are a several frameworks of indicators developed to assess the trends towards sustainable development. The Energy Indicators for Sustainable Development (EISD) have been developed by International Atomic Energy Agency (IAEA) [24]. The EISD is an analytical tool developed which can help energy decision- and policy-makers at all levels to incorporate the concept of sustainable development into energy policy. The EISD set is used to present energy, economic, environmental and social data for policymakers in a coherent and consistent form, showing their linkages and their usefulness for making comparisons, trend analyses and policy assessments. Some indicators from EISD set can be selected and applied for the analysis of the EU energy policies in Member States and for the assessing their success towards implementation of the main targets set by directives and other policies establishing goals for energy efficiency improvements, use of 
renewables and greenhouse gas emission reduction. Therefore indicators relevant to EU energy policies will be selected from the EISD list. The additional indicators to define targets established by EU policies will be developed as well. EISD core set is organized following the conceptual framework used by United Nations Commission on Sustainable Development. There are 30 indicators, classified into three dimensions: social, economic and environmental. Trends in overall energy productivity, supply efficiency, end-use productivity, and fuel mix and energy security will be analysed using economic dimension indicators. Climate change mitigation issues will be addressed by environmental dimension indicators.

The main priorities of EU sustainable energy development policies are: competitiveness, environmental sustainability and security of Supply. In Figure 6 the main priorities of EU energy policy is presented. The main target is competiveness followed by security of supply. The economic competitiveness focuses on the Lisbon strategy and Europe 2020 strategy aiming to make European market the most competitive market in the world. EU also wants to be the role model setting and achieving environmental sustainability objectives, such as reducing $\mathrm{CO} 2$ emissions, increasing the share of renewable energy and improving energy efficiency.

The appropriate EISD were selected to address requirements of EU directives targeting security of supply (ECO15), energy efficiency improvements (ECO1, ECO2), promotion of renewables (ECO11, ECO12, ECO13) and greenhouse gas (ENV1). The selected indicators were grouped by 4 priority areas established by EU energy policy: increase of energy efficiency, use of renewables, increase of energy security and greenhouse gas and other atmospheric emission reduction. The indicators framework for EU energy policy analysis are presented in Table 3.

All these selected EU energy policy indicators can be connected to each other via the chain of mutual impacts based on examples of application of ISED framework in order to develop comprehensive policy framework for monitoring implementation of EU directives and tracking various interacting policy measures targeting relevant indicators. The last indicator in EU energy policy indicators framework

\section{Fig. 6: The main priorities of EU sustainable energy development policy}

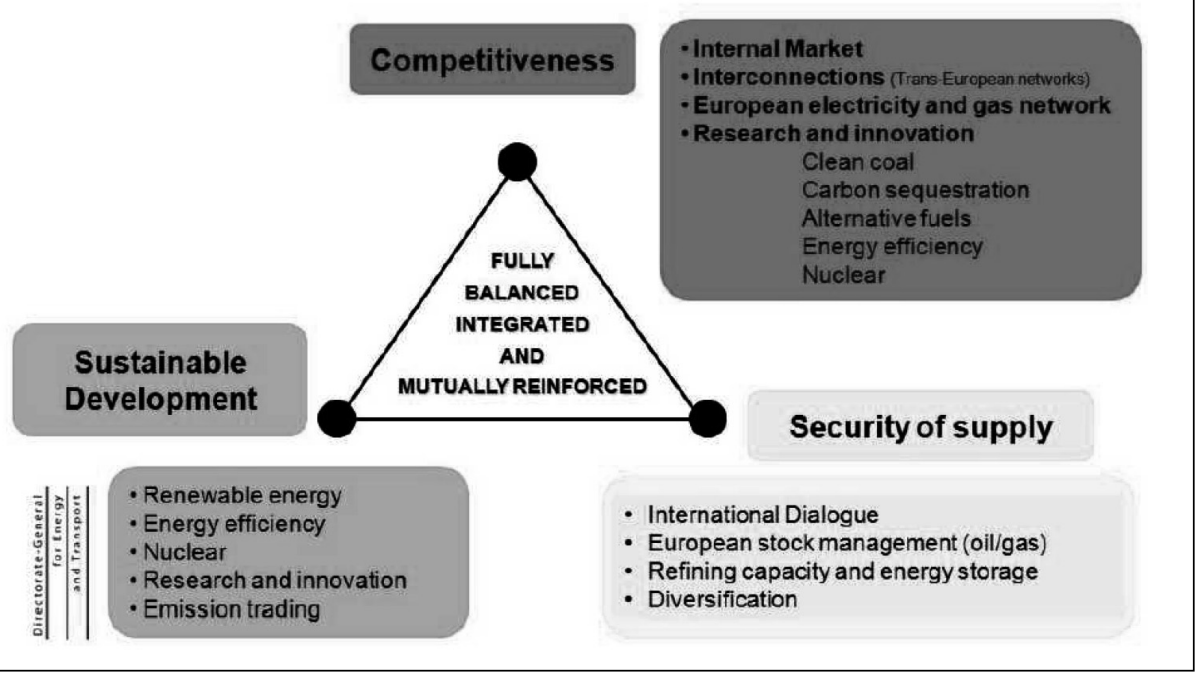

Source: [2] 
is greenhouse gas emission indicator as all other EU policies (targeting energy efficiency improvements, promotion of renewables, and increase in energy supply security) in the end have positive impact on greenhouse gas emission reduction. In the next section of paper the dynamics of the main indicators of sustainable energy development in Baltic States and Czech Republic and Slovakia will be analysed by applying graphical analysis in order to define the best performing country. Based on analysis of environmental tax rates and revenues collected from environmental taxes as percentage of GDP the highest rate of environmental taxes to GDP has Latvia following Estonia however the highest tax rates are in Slovakia and lowest are in Latvia.

\section{Trends of Sustainable Energy Indicators Development in Baltic States, Slovakia and Czech Republic}

The trends of sustainable energy development indicators during 2005-2012 for Baltic States, Czech Republic and Slovakia selected based on Table 3 are presented in Figures 3-9. The most important indicator of sustainable energy development is energy intensity of GDP as this indicator represents also competitiveness, environmental sustainability and energy security issues. Reduce of energy intensity in member states has direct impact on environmental and pollution reduction, climate change mitigation and on increase of competitiveness of economy

\section{Tab. 3: Indicators selected for EU energy policy analysis}

\begin{tabular}{|c|c|c|c|c|c|}
\hline Indicators & Acronym & Subtheme & Directive or policy document & Target & $\begin{array}{c}\text { Date for } \\
\text { achievement }\end{array}$ \\
\hline \multicolumn{6}{|c|}{ Energy efficiency } \\
\hline $\begin{array}{l}\text { Energy intensity of } \\
\text { GDP }\end{array}$ & ECO1 & $\begin{array}{l}\text { Energy } \\
\text { efficiency }\end{array}$ & $\begin{array}{l}\text { Directive 2012/27/EC on energy efficiency, } \\
\text { amending Directives 2009/125/EC and } \\
\text { 2010/30/EU and repealing Directives 2004/8/ } \\
\text { EC and 2006/32/EC }\end{array}$ & $\begin{array}{l}\text { Reduce energy } \\
\text { intensity by } \\
20 \% \text { from year } \\
2005 \text { level }\end{array}$ & 2020 \\
\hline $\begin{array}{l}\text { The share of } \mathrm{CHP} \text { in } \\
\text { electricity production }\end{array}$ & ECO2 & $\begin{array}{l}\text { Energy } \\
\text { efficiency }\end{array}$ & $\begin{array}{l}\text { Directive 2004/8/EC on the promotion of } \\
\text { cogeneration based on a useful heat demand } \\
\text { in the internal energy market and amending } \\
\text { Directive } 92 / 42 / E E C\end{array}$ & $35 \%$ & 2025 \\
\hline \multicolumn{6}{|c|}{ Use of Renewable energy sources) } \\
\hline $\begin{array}{l}\text { The share of } \\
\text { renewables in } \\
\text { electricity generation }\end{array}$ & ECO11 & $\begin{array}{l}\text { Rene- } \\
\text { wables }\end{array}$ & $\begin{array}{l}\text { Directive 2001/77/EC on the promotion of } \\
\text { electricity produced from renewable energy } \\
\text { sources in the internal electricity market }\end{array}$ & $21 \%$ & 2020 \\
\hline $\begin{array}{l}\text { The share of } \\
\text { renewables in fuel } \\
\text { used in transport }\end{array}$ & ECO12 & $\begin{array}{l}\text { Rene- } \\
\text { wables }\end{array}$ & $\begin{array}{l}\text { 2003/30/EC Directive on the promotion of the } \\
\text { use of biofuels or other renewable fuels in } \\
\text { transport }\end{array}$ & $10 \%$ & 2020 \\
\hline $\begin{array}{l}\text { The share of } \\
\text { renewables in final } \\
\text { energy }\end{array}$ & ECO13 & $\begin{array}{l}\text { Rene- } \\
\text { wables }\end{array}$ & $\begin{array}{l}\text { Directive 2009/28/EC on the promotion of } \\
\text { the use of energy from renewable sources } \\
\text { and amending and subsequently repealing } \\
\text { Directives 2001/77/EC and 2003/30/EC }\end{array}$ & $20 \%$ & 2020 \\
\hline \multicolumn{6}{|c|}{ Security of Supply } \\
\hline Energy independency & EC015 & $\begin{array}{l}\text { Security } \\
\text { of supply }\end{array}$ & "2020 Climate and Energy Package" & $50 \%$ & 2030 \\
\hline \multicolumn{6}{|c|}{ Atmospheric pollution reduction } \\
\hline $\begin{array}{l}\text { Greenhouse gas } \\
\text { emissions (CO2 } \\
\text { emissions from } \\
\text { energy sector) }\end{array}$ & ENV1 & $\begin{array}{l}\text { Climate } \\
\text { change }\end{array}$ & "2020 Climate and Energy Package" & $\begin{array}{l}\text { Reduction by } \\
20 \% \text { of year } \\
1990 \text { level }\end{array}$ & 2020 \\
\hline
\end{tabular}


and security of energy supply. In Figure 7 the trends of energy intensity of GDP is compared in Baltic States, Czech Republic and Slovakia.

As one can see from Figure 7 though all Baltic States and Czech Republic and Slovakia have energy intensity well above EU-28 level the highest energy intensity is in Estonia and the lowest one in Lithuania. Comparing data of year 2004 with energy intensity in 2012 one can notice that energy intensity was decreasing since entering EU in all analysed countries however economic crisis had negative impact and energy intensity stared to increase however in Estonia energy intensity increase can be noticed since 2007 but in 2010 this trend has dramatically changed and energy intensity began to decrease. In other analysed countries the trend of energy intensity decrease can be noticed following the recovery from economic crisis in 2010 . Though countries have implemented various policies and measures to ensure energy efficiency energy and pollution taxes have also important effect on energy intensity decrease [26].

Increase of utilisation of renewable energy sources is important priority of environmental sustainability of energy sector development. All countries have introduced additional measures to environmental taxes to increase usage of renewable energy sources [25]. In Figure 8 the trends of important indicator representing penetration of renewables in final energy consumption of Baltic states and Czech Republic and Slovakia are presented.

As one can see from Figure 8 Latvia distinguishes with very high share of renewables in final energy which is well above EU-28 level. In Estonia and Lithuania the share of renewables in final energy is also above EU-28 level and has increased significantly since 2004 (by almost 70\%). The high share of renewables in Latvia is related with the natural conditions and high share of hydro in electricity generation. The lowest share of renewables is in Slovakia and Czech Republic and though since 2004 use of renewables in final energy was increasing in all analysed countries the highest increase was achieved in Estonia. Comparing results achieved by new EU member states with target one can notice that Estonia achieved level above target set for 2020 in 2011. Other countries in 2012 have the shares of renewables well below established target for 2020.

Another important indicator representing progress achieved by EU member states in

\section{Fig. 7: Development of energy intensity of the economy in Baltic States, Czech Republic and Slovakia}

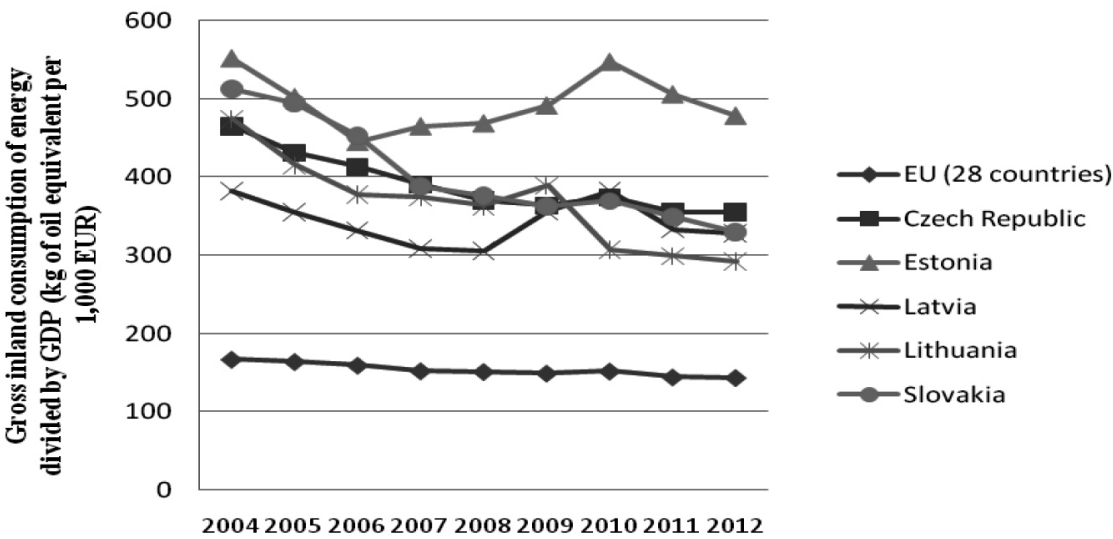



and target for 2020

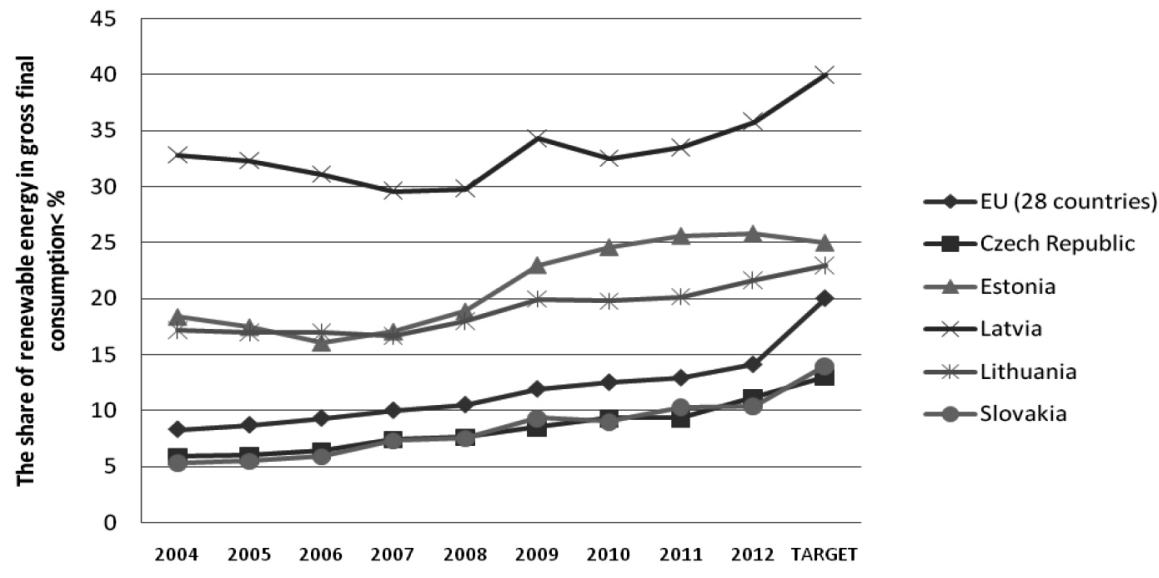

Source: EUROSTAT

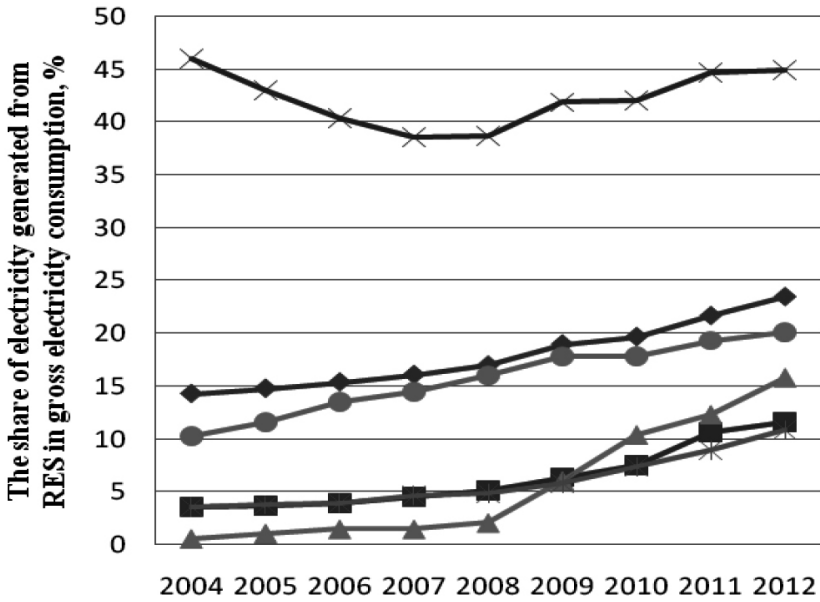


implementing EU energy policy targets is the share of renewables in electricity generation. In Figure 9 the trends of electricity generated from renewable energy sources in Baltic States, Czech Republic and Slovakia are presented.

As one can see from Figure 9 Latvia again distinguishes with very high shares of renewables in gross electricity consumption between analysed countries. As hydro energy production depends on the weather conditions the share of electricity generated from hydro is fluctuating in Latvia. All other new EU member states have thes share of electricity generated from renewables well bellow EU-28 average level. In all countries the trends of increase of electricity generated from renewables can be noticed. Slovakia has the highets share of electricity generated from renewables $(20 \%)$ between other countries included in analysis except Latvia. Lithuania and Czech Republic have very similar shares in 2012 - slightly above $12 \%$. In all ananlysed countries the continuos trend of increase of the share of renewables in electricity generation can be noticed during 2004-2012 year period. The highets increase is achieved in Estonia.
In Figure 10 the trends of use of renewable energy in transport in Baltic States and Czech Republic and Slovakia are prsented during 2004-2012 year period.

As one can see from Figure 10 the Estonia distinguishes with very low shares of renewables in fuels used in transport. The highest share of renewables in transport fuel consumption well above EU-28 level was in Czech Republicin 2012 though in 2011 country has experienced sharp decrease in renewables consumption in transport. Slovakia and Lithuania also has achieved high share of renewables in fuel consumption in transport in 2012 - almost $5 \%$ and are in libne with requirements set by $2003 / 30 / E C$ Directive on the promotion of the use of biofuels or other renewable fuels in transport.

The combined heat and power production allow to increase significantly energy efficiency therefore it is important indicator of environmental sustainability achieved by EU member states. In Figure 11 the development of combined heat and power generation in gross electricity generation in Baltic States, Czech Republic and Slovakia is presented.

As one can see from Figure 11 the highest share of combined heat and power (CHP)

\section{Fig. 10: Development of the use of renewable energy in fuel consumption of transport in Baltic States, Czech Republic and Slovakia}

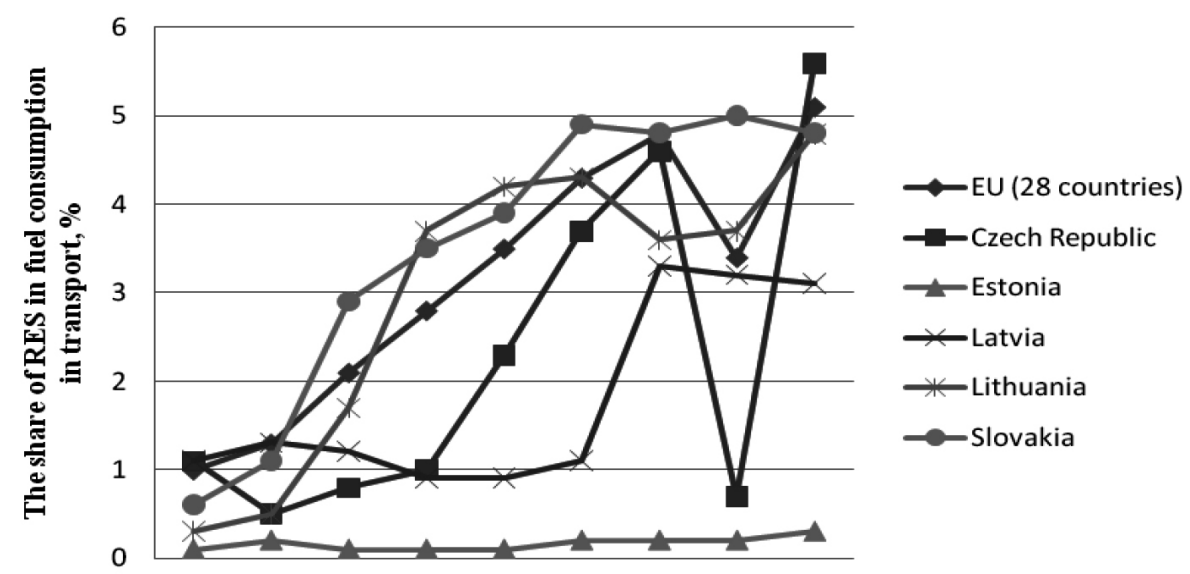

200420052006200720082009201020112012 


\section{Fig. 11: Development of combined heat and power generation in gross electricity generation in Baltic States, Czech Republic and Slovakia}

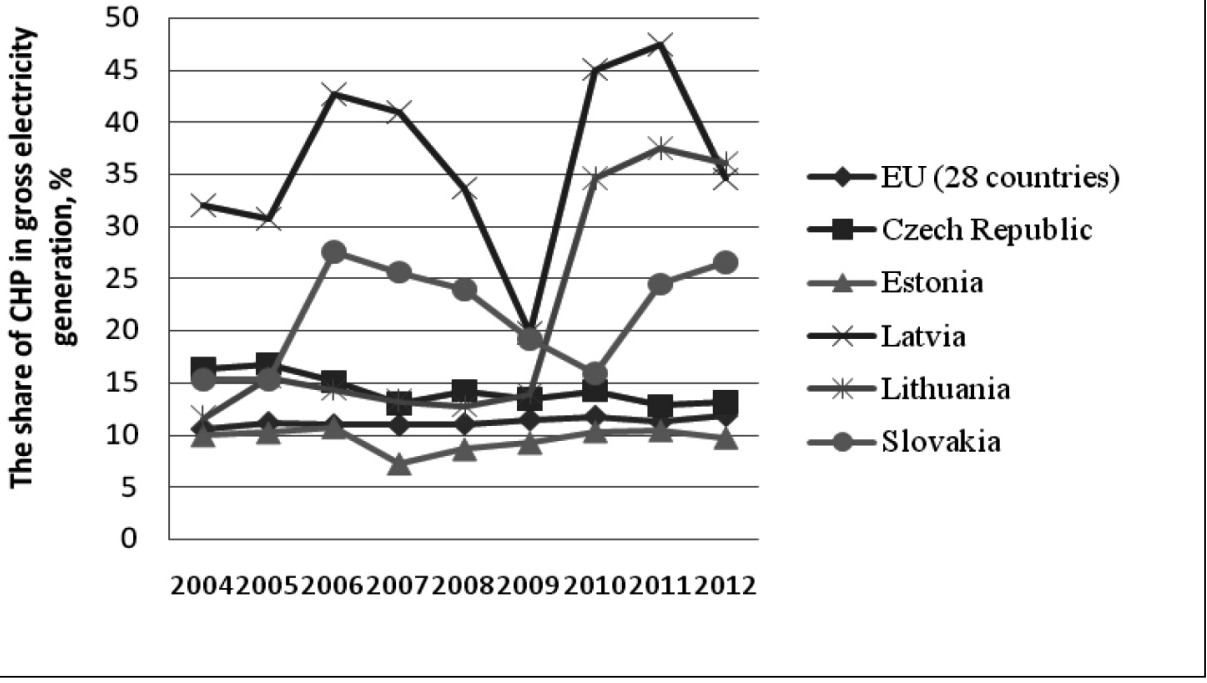

in gross electricity generation is achieved in Lithuania and Latvia though in Latvia because of the high share of hydro in gross electricity generation there are big fluctuations of the share of CHP in gross electricity generation during investigated period. Estonia has quite low share of $\mathrm{CHP}$ in gross electricity generation even bellow EU-28 average. In other analysed countries the share of CHP in gross electricity generation is above EU-28 level. Especially high increase of $\mathrm{CHP}$ in gross electricity generation can be noticed in Lithuania (from $10 \%$ to $36 \%$ ) and Slovakia (from $15 \%$ to $27 \%$ ) during investigated period.

GHG emissions is important indicator of energy sector sustainability and expresses results achieved in other indicators of sustainable energy development: energy efficiency improvements and increase of the share of renewables as these are major ways to reduce GHG emissions from fuel combustion. In Figure 12 the development of GHG emission intensity of energy consumption in Baltic States and Czech Republic and Slovakia is presented. This ratio indicator is selected instead of total GHG emissions for the comparison between countries as indicator of total GHG emissions do not allow to compare countries because of the difference in size of economy.

As one can see from Figure 12 the Czech Republic has achieved the best results of GHG emission reduction in energy sector following Estonia. The worst situation with this indicator is in Lithuania because of the closure of Ignalina NPP in 2009 and the increase of fossil fuel consumption replacing carbon free nuclear fuels. However since 2010 the trends are positive and carbon intensity of energy is also decreasing in Lithuania. Slovakia achieved significant decrease of carbon intensity of energy since 2004. The Slovak Republic is one of the countries that have managed to curb down greenhouse gas emissions considerably since 1990 . At the same time, it is progressing well in decoupling the economic growth from emissions. Estonia also reached good results in decreasing of carbon intensity of energy because of good results achieved in penetration of renewable energy sources in energy sector except renewables used in transport sector.

In Figure 13 the trends of energy dependency in Baltic States and Czech Republic and Slovakia are presented. 


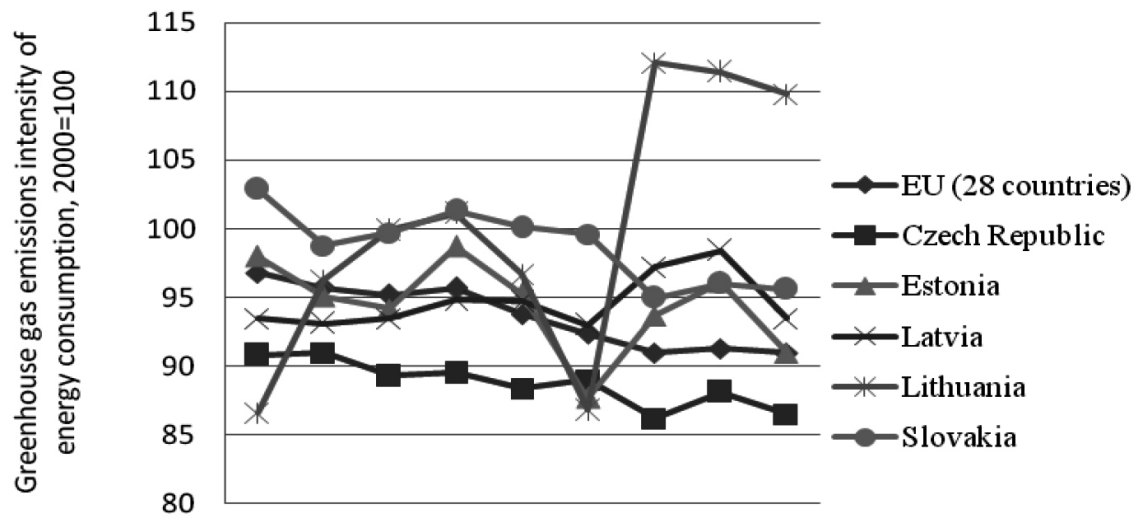

200420052006200720082009201020112012

Source: EUROSTAT

As one can see from Figure 13 the highest energy dependency rate in 2012 was in Lithuania. This is related with the closure of Ignalina NPP in 2009 and increase of energy import. Before closure of Ignalina NPP Lithuania was net energy exporter. The lowest energy import dependency is in Estonia though it has slightly decrease in 2012 comparing with year 2011. Estonia has abundant oil shale resources and has been utilising these resources in energy sector quite intensively however with entrance in force of stringent EU environmental regulations the use of oil shale having high sulphur content is diminishing. Czech Republic also has quite low energy import dependency because of availability local coal resources. Slovakia and Latvia have high energy dependency rate well above EU-28 level however the trends in Latvia and Slovakia are very positive and energy dependency rates have decreased in these countries from almost $70 \%$ in 2004 to $55-60 \%$ in 2012.

\section{Conclusions}

The main benefits of greening national tax system is related with double dividends such as economic growth because and reduction of environmental impact because of the changes of tax structure from taxes on labor and income to the environmental and resource taxes.

Energy sector is the major source of environmental pollution therefore increase in environmental taxes is anticipated to have positive impact on sustainable energy development which means competitive, secure and environmentally sound energy sector development

The process of greening national tax systems in all European Union is undergoing however there significant differences among new EU member states. Analysis of environmental taxes in three Baltic States and Czech Republic indicated quite different energy and pollution tax rates as well as quite large differences in the share of environmental tax revenues as percentages of GDP in these countries.

The conducted analysis revealed that Estonia distinguishes from analysed fifth countries with the best results in greening environmental tax system. The highest rates of pollution and energy taxes imposed in Estonia also provides for high shares of environmental taxes as the percentages of GDP in this 


\section{Fig. 13: The trends of energy dependency rates in Baltic States, Czech Republic and Slovakia}

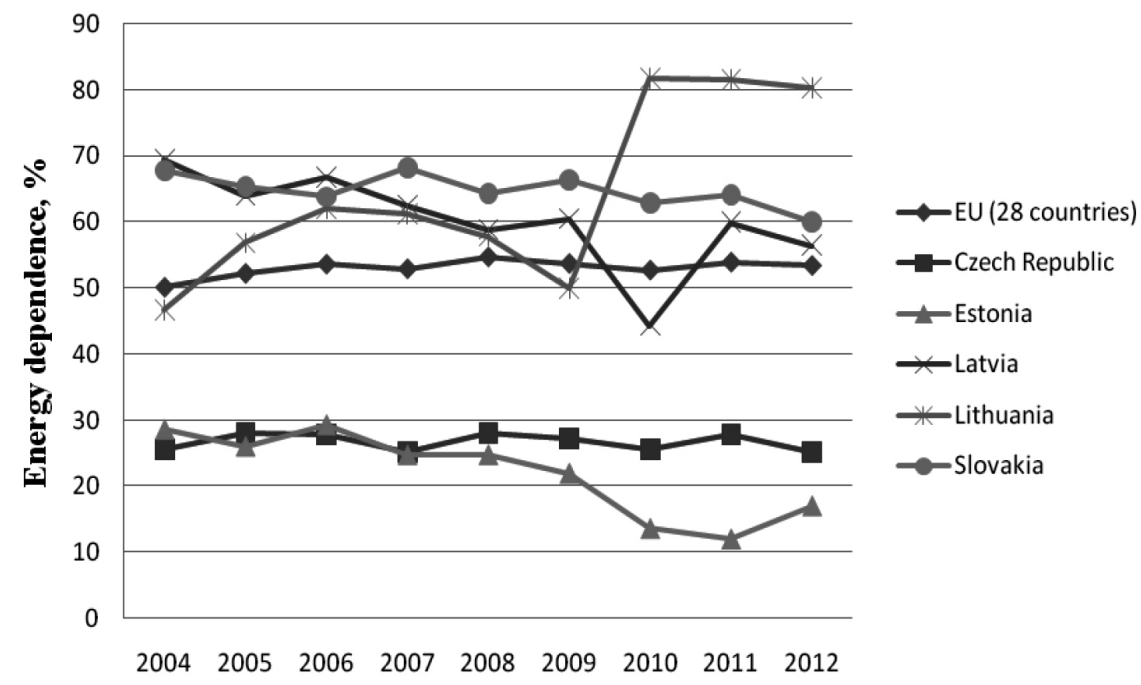

Source: EUROSTAT

country. Latvia has one of the lowest shares of environmental taxes as percentage of GDP. Low revenues from environmental taxes could signal relatively low environmental tax rates, or could result from high tax rates that have had the effect of changing behavioural patterns of consumption of the related products or activities.

Higher levels of environmental tax revenue could be due to low tax rates that incentivise non-residents to purchase taxed products across a border (as is the case for petrol or diesel).

Though there are other policies and measures to promote sustainable energy development in selected countries such feed-in prices for electricity produced from renewable energy sources, subsides from EU Structural Funds etc. environmental taxes relevant to energy sector may also play important role in promoting sustainable energy development.

Comparing Baltic States and Czech Republic and Slovakia in terms of progress achieved in sustainable energy development and meeting EU energy policy targets several indicators of sustainable energy development were selected. The trends of security of energy supply, energy efficiency, penetration of renewable energy sources and GHG emissions were compared among five new EU member states.

Estonia distinguishes from analysed countries with good results achieved in achieving several sustainable energy development targets, such as high share of renewables in final energy consumption, high security of energy supply (low rate of energy independency), significant decrease in energy intensity and carbon intensity of energy. Czech Republic has achieved good results in increase of security of energy supply and decrease of energy intensity of GDP and carbon intensity of energy. Latvia distinguishes with very high shares of renewables in electricity generation and in final energy consumption however it is more related with favourable climate conditions and well developed hydro power plants.

The improvements of environmental tax systems give a relevant and strong motive for the sustainable energy development in the countries. Certainly the evolution of environmental taxes is based on historical 
heritage of the European Union and economic aspects such as the level of economic development, size of the state, population and other reasons. Because of steady development and growing of standard of living, which environment is part of, the tax greening is anticipated to be continued in all analysed countries.

\section{References}

[1] AARHUS UNIVERSITY. Study on Environmental Fiscal Reform Potential in 12 EU Member States. No 07.0307/ETU/2013/ SI2.664058/ENV.D.2 Final Report to DG Environment of the European Commission [online]. Aarhus: University of Aarhus, 201402-28 [cit. 2015-05-04]. 827 p. (PDF). Available from: http://ec.europa.eu/environment/ integration/green_semester/pdf/EFR-Final\%20 Report.pdf.

[2] $\mathrm{BACH}, \mathrm{S}$. The effects of environmental fiscal reform in Germany: a simulation study. Elsevier Energy Policy. 2002, Vol. 30, Iss. 9, pp. 803-811. ISSN 0301-4215. DOI: http://dx.doi. org/10.1016/S0301-4215(02)00005-8.

[3] BACH, S., et al. The effect of environmental fiscal reform in Germany: a simulation study. Energy policy. 2002, Vol. 30, Iss. 9, pp 803811. ISSN 0301-4215. DOI: 10.1016/S03014215(02)00005-8.

[4] BARKER, T., KÖHLER, J. Equity and eco tax reform in the EU: achieving a 10 per cent reduction $\mathrm{CO} 2$ emissions using excise duties. Fiscal Studies. 1998, Vol. 19, Iss. 4, pp. 375402. ISSN 0143-5671.

[5] BAYINDIR-UPMANN, T., RAITH, M.G. Should high tax countries pursue revenueneutral ecological tax reforms? European Economic Review. 2003, Vol. 47, Iss. 1, pp. 41-60. ISSN 0014-2921. DOI: 10.1016/S00142921(01)00193-3.

[6] BOVENBERG, L. Green tax reforms and the double dividend: an updated reader's guide. International Tax and Public Finance. 1999, Vol. 6, Iss. 3, pp. 421-443. ISSN 1573-6970. DOI: 10.1023/A:1008715920337.

[7] BOVENBERG, L., DE MOOIJ, R.A. Environmental levies and distortionary taxation. American Economic Review. 1994, Vol. 84, Iss. 4, pp. 1085-1089. ISSN 0002-8282.

[8] BOVENBERG, L., SMULDERS, S. Transitional impacts of environmental policy in an endogenous growth model. International
Economic Review. 1996, Vol. 37, Iss. 4, pp. 861-893. ISSN 1468-2354.

[9] CUMMINS, J.G., HASSETT, K.A., HUBBARD, R.G. Tax reforms and investment: a cross-country comparison. Journal of Public Economics. 1996, Vol. 62, Iss. 1-2, pp. 237273. ISSN 0047-2727. DOI: 10.1016/00472727(96)01580-0.

[10] DE MOOIJ, R. Environmental Taxation and the Double Dividend. Contributions to Economic Analysis. Amsterdam: North Holland, 2000. ISBN 978-0-444-50491-3.

[11] EKINS, P., DRESNER, S. Green taxes and charges: reducing their impact on low-income households. London: Policy Studies Institute, 2004. ISBN 1-85935-247-2.

[12] EUROPEAN COMMISSION. Tax reforms in EU Member States. Tax policy challenges for economic growth and fiscal sustainability [online]. Brussels: EC, 2012-06 [cit. 2015-05-14]. Working paper No. 34-2012, 06/2012. Available from: http://ec.europa.eu/taxation_customs/resources/ documents/taxation/gen_info/economic analysis/ tax_papers/taxation_paper_34_en.pdf.

[13] EUROPEAN COMMISSION. Tax reforms in EU Member States 2013 of European Commission [online]. Brussels: EC, 2013 [cit. 2015-05-14]. Available from: http://ec.europa. eu/taxation_customs/resources/documents/ taxation/gen_info/economic_analysis/ taxpapers/taxation_paper_38.pdf.

[14] EUROPEAN COMMISSION. Excise Duty Tables. Part II - Energy products and Electricity [online]. Brussels, EC, 2015-07 [cit. 2015-05-04]. 78 p. (PDF). Available from: http:// ec.europa.eu/taxation_customs/resources/ documents/taxation/excise_duties/energy_ products/rates/excise_duties-part_ii_energy_ products_en.pdf.

[15] EUROPEAN COMMISSION. Environmental taxes - revised statistical guide [online]. Brussels: EC, 2013 [cit. 2015-05-14]. Available from: http://epp.eurostat.ec.europa.eu/cache/ ITY OFFPUB/KS- GQ-13-005/EN/KS-GQ-13005-EN.PDF. ISSN 2315-0815.

[16] EUROPEAN ENVIRONMENT AGENCY. Environmental taxes: recent developments in tools for integration. [online] Copenhagen: EEA, 2000 [cit. 2015-05-11]. Environmental issues series No. 18. 92 p. (PDF). Available from: http://edz.bib.uni-mannheim.de/daten/edz-bn/ eua/00/envissue18.pdf. ISBN 92-9167-261-0.

[17] EUROPEAN ENVIRONMENT AGENCY. Environmental tax reform in Europe: implications 
for income distribution [online]. Copenhagen: EEA, 2011-11-25 [cit. 2015-05-20]. Technical report No 16/2011. Available from: http://www. eea.europa.eu/publications/environmental-taxreform-in-europe/.

[18] GOULDER, L.H. Environmental taxation and the "double dividend": A reader's guide. International Tax and Public Finance. 1995, Vol. 2, Iss. 2, pp. 157-183. ISSN 1573-6970. DOI: 10.1007/BF00877495.

[19] INSTITUTE FOR EUROPEAN ENVIRONMENTAL POLICY. Evaluation of environmental tax reforms: international experiences, Final report [online]. Brussels: IEEP, 2013-06-21 [cit. 2015-06-01]. 84 p. (PDF). Available from: http://www.ieep.eu/ assets/1283/ETR_study_by_IEEP_for_the Swiss_Government_-_Final_report_-_21_ June_2013.pdf.

[20] JORGENSON, D.W., WILCOXEN, P.J. Reducing U.S. carbon dioxide emissions: An econometric general equilibrium assessment. Resource and Energy Economics. 1993, Vol. 15 , Iss. 1, pp. 7-25. ISSN 0928-7655. DOI: 0.1016/0928-7655(93)90016-N.

[21] KOSKELA, E., SCHOB, R. Alleviating unemployment: The case for green tax reforms. European Economic Review. 1999, Vol. 43, Iss. 9, pp. 1723-1746. ISSN 0014-2921. DOI: 10.1016/S0014-2921(98)00043-9.

[22] LUCAS, R.E. Supply side economics: An analytical review. Oxford Economic papers. 1990, Vol. 42, Iss. 2, pp. 293-316. ISSN 1464-3812.

[23] MCNALLY, R.H.G., MABEY, N. The distributional impacts of ecological tax reform. United Kingdom: WWF, 1999.

[24] STREIMIKIENE, D., MIKALAUSKIENE, A., BARAKAUSKAITE-JAKUBAUSKIENE, N. Sustainability Assessment of Policy Scenarios. Transformation in Business \& Economics. 2011, Vol. 10, Iss. 2, pp. 168-165. ISSN 1648-4460.

[25] STREIMIKIENE, D., SARVUTYTEGRIGALIUNIENE, M. Impact of renewables on employment in Lithuania. Transformations in Business \& Economics. 2012, Vol. 11, Iss. 1, pp. 167-184. ISSN 1648-4460.

[26] VASAUSKAITE, J., STREIMIKIENE, D. Review of Energy Efficiency Policies in Lithuania. Transformations in Business \& Economics. 2014, Vol. 13, Iss. 3C, pp. 628-643. ISSN 1648-4460.

[27] ZHANG, Z.X. Macroeconomic effects of CO2 emissions limits: a computable general equilibrium analysis for China. Journal of Policy Modeling. 1998, Vol. 20, Iss. 2, pp. 213250. ISSN 01618938. DOI: 10.1016/S01618938(97)00005-7.

\section{prof. Dalia Štreimikienè, Ph.D.} Vilnius University Kaunas Faculty of Humanities dalia.streimikiene@khf.vu.It 


\section{IMPACT OF ENVIRONMENTAL TAXES ON SUSTAINABLE ENERGY DEVELOPMENT IN BALTIC STATES, CZECH REPUBLIC AND SLOVAKIA}

\section{Dalia Štreimikienè}

Environmental taxes have direct impact on sustainable energy development as energy production and consumption is the major source of GHG and classical pollutants emissions. There are number of EU member states which are using environmental pollution taxes as the main economic instrument of atmospheric air pollution reduction. The energy sector is the main source of atmospheric pollution therefore environmental taxes should have direct impact on sustainable energy development as these taxes create incentives to reduce consumption of fossil fuels and to switch to renewables and cleaner fossil fuels such as natural gas. The comparative study of environmental taxes and indicators of sustainable energy sector development in Baltics and Czech Republic and Slovakia was performed to assess what role environmental taxes are playing in achieving sustainable energy development in selected new EU member states.

Analysis of environmental taxes in three Baltic States and Czech Republic indicated quite different energy and pollution tax rates as well as quite large differences in the share of environmental tax revenues as percentages of GDP in these countries. Estonia distinguishes with the best results in greening environmental tax system and one of the best results in achieving sustainable energy development targets. Latvia has one of the lowest share of environmental taxes as percentage of GDP and has very high shares of renewables in electricity generation and in final energy consumption however it is more related with favourable climate conditions and well developed hydro power plants.

Key Words: Environmental taxes, sustainable energy development, indicators, Baltic States, Czech Republic, Slovakia.

JEL Classification: E62, Q01, Q43, Q56.

DOI: $10.15240 / t u l / 001 / 2015-4-001$ 